\title{
Efektivitas Teknik Konseling Cognitive Behavioral untuk Meningkatkan Self-Efficacy Siswa Pada Pelajaran Matematika
}

\author{
Sopiyah $^{1 *}$, Juntika Nurikhsan ${ }^{2}$ dan Anne Hafina ${ }^{2}$ \\ ${ }^{1}$ Bimbingan dan Konseling SMAN 2 Bandung, Indonesia \\ ${ }^{2}$ Sekolah Pascasarjana Universitas Pendidikan Indonesia, Bandung, Indonesia \\ *sophie_udi@yahoo.com.au
}

\begin{abstract}
Abstrak
Paper ini memaparkan tentang pengaruh cognitive behavioral therapy (CBT) dalam meningkatkan self-efficacy siswa yang rendah pada pelajaran matematika. Metode kuantitatif dengan pendekatan single subject digunakan pada penelitian ini melalui desain A-B. Subjek penelitian adalah siswa kelas XI-MIA yang memiliki self-efficacy rendah pada pelajaran matematika. Hasil penelitian menunjukkan bahwa teknik konseling CBT efektif untuk meningkatkan self-efficacy siswa pada pelajaran matematika. Efektifitas tersebut tampak pada perbandingan skor rata-rata baseline dan skor pasca intervensi yang dilukiskan dengan grafik pada masing-masing subjek penelitian. Rekomendasi yang dapat disampaikan bahwa guru-guru bimbingan dan konseling diharapkan menjadikan teknik konseling CBT dijadikan salah satu alternatif untuk meningkatkan self-efficacy dan performa siswa pada pelajaran matematika. Guru mata pelajaran matematika diharapkan tidak sekedar hanya menjelaskan materi yang diajarkan, namun juga diharapkan dapat melakukan penguatan keyakinan dan kemampuan siswa terhadap pelajaran matematika. Disarankan untuk penelitian berikutnya, agar dapat memperluas subjek penelitian tidak hanya pada jenjang SMA, melainkan pada jenjang SMP dan SD, juga untuk bidang-bidang pelajaran lain selain matematika pada siswa kurang atau tidak memiliki keyakinan yang cukup, serta menguji keefektifan teknik konseling CBT dalam setting kelompok.
\end{abstract}

Kata kunci: konseling cognitive behavioral, self-efficacy.

\begin{abstract}
This paper discusses the effect of CBT in improving students' low self-efficacy on mathematics. Method being used was quantitative as well as single subject approach with A-B design. The target group being used were students of XI-MIA class. Results of research indicated that CBT was effectively improved students' self-efficacy on mathematics. Students' self-efficacy of post intervention was higher than pre intervention of CBT for each single subject of study. The authors recommended for the counseling teachers to use CBT as one of the techniques to improve students' selfefficacy on mathematics. The teacher of mathematics were also expected not only delivered mathematical contents, but also are expected to strengthen students' beliefs and self-efficacy on mathematics. For the following researchers, we would like to suggest to enlarge subjects not only for senior secondary classroom, but also for junior high school and primary school classroom. Suggestion also were addressed for subjects other than mathematics that students have lower self-efficacy, and with group setting.
\end{abstract}

Keywords: counseling of cognitive behavioral, self-efficacy.

\section{PENDAHULUAN}

Berawal dari sebuah keprihatinan bahwa anak-anak yang kurang memiliki percaya diri dan memiliki self-efficacy rendah seringkali memiliki prestasi yang kurang 
beruntung termasuk dalam matematika. Padahal matematika merupakan pelajaran yang penting untuk bisa menghadapi kehidupan mendatang. Pentingnya belajar matematika tidak lepas dari manfaat matematika itu sendiri dalam kehidupan. Ada peranan penting matematika dalam berbagai disiplin ilmu dan memajukan daya pikir manusia (Priatna, 2008:47), seperti kemampuan berpikir logis, analitis, sistematis, kritis, dan kreatif, serta kemampuan bekerjasama (Auliya, 2013:1).

Kesenjangan yang terjadi pada umumnya adalah persepsi negatif siswa pada mata pelajaran matematika. Mereka merasakan bahwa matematika sukar, gersang, dan mereka mengira bahwa matematika tidak ada kaitannya dengan kehidupan sehari-hari (Hidayat, 2010). Beberapa siswa merasa bahwa matematika adalah mata pelajaran yang rumit untuk dipelajari sehingga mereka merasa tidak percaya diri pada kemampuan dirinya untuk mengatasi masalah matematika di sekolahnya (Tansil, Aditomo \& Tjahjono, 2009). Ada dampak jika persepsi negatif tersebut terus berkembang seperti dapat memunculkan perilaku yang menghambat prestasi siswa pada pelajaran matematika.

Weinstein (dalam Lusby, 2009) menemukan bahwa kondisi siswa merasa bosan dalam belajar matematika maka mereka tidak menikmati kelas dan lebih cenderung mengabaikan atau hanya menurut saja (hanya mengikuti yang ditugaskan oleh guru), di mana kedua kondisi tersebut berdampak pada produktivitas dan partisipasi di kelas. Sikap negatif yang tergambar berdasarkan temuan tersebut, sikap negatif yang tergambar mengarah kepada motivasi yang rendah dan apatis pada pengembangan keilmuan di bidang matematika yang dipengaruhi oleh self-efficacy (Lusby, 2009). Selain itu, kecemasan terhadap matematika ditambah dengan selfefficacy yang rendah maka dapat menghambat dalam proses pengajaran matematika (Hellum-Alexander, 2010: 101). Peserta didik yang merasa cemas saat belajar matematika maka mereka cenderung menghindari (Sloan, Daane \& Giesen, 2002).

Siswa dengan kecemasan yang tinggi dalam mata pelajaran matematika cenderung ketakutan dan perilaku menghindar, yang seringkali mengganggu kinerja dalam kehidupan sehari-hari maupun dalam situasi akademis (Bandura, 1997:137). Perilaku menghindar adalah bentuk yang sering muncul pada siswa yang tingkat kecemasannya tinggi dan self-efficacy yang rendah. Beberapa studi penelitian tentang hubungan antara self-efficacy dan kecemasan mengungkapkan bahwa individu yang mengalami kecemasan akan terlihat pada mereka saat belajar matematika seperti keluar dari kelas, mengerjakan kegiatan lain, sehingga akan mengganggu proses belajar mengajar (Sopiyah, 2016). Hasil studi Sopiyah (2016) terhadap siswa kelas XI di sebuah SMA memperlihatkan bahwa: (a) sering terlihat siswa keluar kelas di jam belajar, mereka mengaku kalau dirinya sulit memahami pelajaran matematika, sehingga selalu ingin keluar ketika mata pelajaran tersebut; (b) beberapa siswa berpendapat bahwa mereka belajar ataupun tidak, maka tetap merasa tidak mudah untuk memahami konsep matematika; (c) ketika masuk jam pelajaran matematika, siswa merasa tidak bersemangat mengikuti pelajaran tersebut; (d) guru matematika kelas tersebut menerangkan bahwa,berdasarkan analisis nilai ulangan harian dan partisipasi di kelas perkembangan kemampuan matematika siswa kurang terlihat. Hal ini sesuai dengan studi Weinstein (dalam Lusby, 2009) bahwa siswa dengan karakteristik di atas perlu diberikan intervensi pada self-efficacy mereka.

Bandura (1993) menyatakan bahwa self-efficacy merupakan kepercayaan individu untuk mampu mencapai kesuksesan. Dari kepercayaan tersebut akan 
muncul perilaku dan kebiasaan untuk mencapai hasil yang diinginkan. Self-efficacy membantu dalam mendorong besar kecilnya usaha yang akan dikeluarkan orang dalam suatu aktivitas, bagaimana mereka gigih ketika menghadapi rintangan, dan mengukur kemampuan diri pada saat situasi yang kurang cocok. Menurut teori kognitif sosial Bandura (1994), self-efficacy mempengaruhi pilihan orang dalam menjalankan suatu tindakan yang mereka capai. Individu cenderung berkonsentrasi dalam tugas yang dirasa mampu akan dapat menyelesaikannya serta menghindari tugas yang sekiranya mereka tidak mampu mengerjakannya (Mukhid, 2009). Oleh karena itu, mengubah self-efficacy berarti membarui pola pikir sehingga jenis konselingnya adalah konseling kognitif-perilaku, atau dikenal dengan istilah CBT (Sopiyah, 2016).

CBT merupakan perpaduan antara terapi kognitif dan behavioral (Bush, 2003). Terapi kognitif diasumsikan pada pikiran dan kepercayaan (efikasi diri), sedangkan terapi tingkah laku adalah untuk membangun hubungan antara solusi permasalahan dan kebiasaan mereaksi masalahnya. Paper ini menguji bagaimana efektivitas dari CBT untuk meningkatkan self-efficacy siswa pada bidang matematika.

\section{Cognitive Behavioral Therapy (CBT)}

Kajian tentang CBT tidak lepas dari tokohnya, yaitu Beck (1964) yang mendefinisikan CBT sebagai salah satu pendekatan konseling. Tujuan dirancangnya CBT adalah untuk menyelesaikan masalah konseling kognitif yaitu restrukturisasi kognitif dan perilaku peserta didik yang menyimpang. Pendekatan CBT didasarkan pada formulasi kognitif, keyakinan, dan strategi perilaku yang mengganggu. Proses konseling didasarkan pada konseptualisasi atau pemahaman konseli atas keyakinan khusus dan pola perilaku konseli (Erfantinni, Purwanto \& Japar, 2016). Harapan dari CBT yaitu munculnya restrukturisasi kognitif yang menyimpang dan sistem kepercayaan untuk membawa perubahan emosi dan perilaku ke arah yang lebih baik.

Matson \& Ollendick (1988:44) mendefinisikan CBT sebagai suatu pendekatan dengan sejumlah prosedur yang secara spesifik menggunakan kognisi sebagai bagian utama konseling. Fokus konseling yaitu persepsi, kepercayaan, dan pikiran. Para ahli yang tergabung dalam National Association of Cognitive Behavioral Therapists (NACBT, 2007) mengungkapkan bahwa CBT yaitu suatu pendekatan psikoterapi yang menekankan peran penting dalam berpikir bagaimana kita merasakan dan apa yang kita lakukan.

Bush (2003) mengungkapkan bahwa CBT merupakan perpaduan dari dua pendekatan dalam psiko terapi yaitu cognitive therapy dan behavior therapy. Terapi kognitif memfokuskan pada pikiran, asumsi, dan kepercayaan. Terapi kognitif memfasilitasi individu belajar mengenali dan mengubah kesalahan. Terapi kognitif tidak hanya berkaitan dengan positive thinking, tetapi juga dengan happy thinking. Sedangkan terapi tingkah laku embantu untuk membangun hubungan antara situasi permasalahan dengan kebiasaan dalam memberikan reaksi permasalahan. Individu belajar mengubah perilaku, menenangkan pikiran dan tubuh sehingga merasa lebih baik, berpikir lebih jelas, dan membantu membuat keputusan yang tepat.

Teori Cognitive-Behavior (Oemarjoedi, 2003:6) pada dasarnya meyakini bahwa pola pemikiran manusia terbentuk melalui proses Stimulus-Kognisi-Respon (SKR), yang saling berkaitan dan membentuk semacam jaringan S-K-R dalam otak 
manusia, di mana proses kognitif menjadi faktor penentu dalam menjelaskan bagaimana manusia berpikir, merasa, dan bertindak.

Tujuan konseling CBT menurut Oemarjoedi (2003: 9) yaitu mengajak konseli untuk menentang pikiran dan emosi yang salah dengan menampilkan bukti-bukti yang bertentangan dengan keyakinan mereka tentang masalah yang dihadapi. Diharapkan kepada konselor agar mampu menolong konseli mencari keyakinan yang bersifat dogmatis pada konseli tersebut untuk mencoba mengurangi emosinya. Dalam proses konseling, beberapa ahli CBT (NACBT, 2007; Oemarjoedi, 2003) berasumsi bahwa masa lalu tidak perlu menjadi fokus penting dalam konseling. Oleh sebab itu BT dalam pelaksanaan konseling lebih menekankan kepada masa kini tetapi tidak mengabaikan masa lalu. CBT tetap menghargai masa lalu sebagai bagian dari hidup konseli dan mencoba membuat konseli menerima masa lalunya, untuk tetap melakukan perubahan pada pola pikir masa kini untuk mencapai perubahan di waktu yang akan datang (Yahya \& Megalia, 2016). Oleh sebab itu, CBT lebih banyak bekerja pada status kognitif saat ini untuk dirubah dari status kognitif negatif menjadi status kognitif positif.

CBT merupakan konseling yang menitikberatkan pada restrukturisasi atau pembenahan kognitif yang menyimpang akibat kejadian yang merugikan dirinya baik secara fisik maupun psikis dan lebih melihat ke masa depan dibanding masa lalu (Erfantinni dkk., 2016). Lebih lanjut, aspek kognitif dalam CBT antara lain mengubah cara berpikir, kepercayaan, sikap asumsi, imajinasi, dan memfasilitasi konseli belajar untuk mengenali, dan mengubah kesalahan dalam aspek kognitif. Sedangkan aspek behavioral dalam CBT yaitu mengubah hubungan yang salah antara situasi permasalahan dengan kebiasaan mereaksi permasalahan, belajar mengubah perilaku, menenangkan pikiran dan tubuh sehingga merasa lebih baik, serta berpikir lebih jelas.

Adapun prinsip-prinsip CBT menurut Beck (2011) bahwa (a) CBT didasarkan pada formulasi yang terus berkembang dari permasalahan konseli dan konseptualisasi kognitif konseli; (b) CBT didasarkan pada pemahaman yang sama antara konselor dan konseli terhadap permasalahan yang dihadapi konseli; (c) CBT memerlukan kolaborasi dan partisipasi aktif dari peserta; (d) CBT berorientasi pada tujuan dan berfokus pada permasalahan; (e) CBT berfokus pada kejadian saat ini; (f) CBT merupakan edukasi yang bertujuan mengajarkan konseli untuk menjadi terapis bagi dirinya sendiri, dan menekankan pada pencegahan; (g) CBT berlangsung pada waktu yang terbatas; (h) sesi-sesi dalam CBT sangat terstruktur; (i) CBT mengajarkan konseli untuk mengidentifikasi, mengevaluasi dan menanggapi pemikiran yang "disfunctional" dan keyakinan mereka; (j) CBT menggunakan berbagai macam teknik untuk mengubah pemikiran, perasaan, dan tingkah laku.

\section{Self Efficacy}

Secara etimologis self-efficacy memuat dua kata yaitu "self" dan "efficacy". Self diartikan sebagai unsur atau struktur kepribadian, sedangkan efficacy adalah penilaian diri mengenai kemampuan untuk melakukan tindakan yang dipandang baik atau dipandang buruk, tetap salah, bisa atau tidak bisa mengerjakan sesuai dengan yang disyaratkan (Alwisol, 2010). Self-efficacy adalah kekuatan tentang keyakinan seseorang terhadap kemampuan dirinya untuk menyelesaikan tugas atau mencapai tujuan (Ormrod, Anderman \& Anderman, 2006). Self-efficacy seseorang 
mempengaruhi setiap bidang usaha manusia. Bandura (dalam Luszczynska, Muhamed, \& Schwarzer, 2005) mendefinisikan self-efficacy sebagai keyakinan seseorang tentang kemampuannya untuk sukses dalam situasi spesifik tertentu. Bandura (1997) menambahkan bahwa keyakinan pribadi mempengaruhi tindakan, usaha, ketekunan, kegembiraan atas perbedaan, dan wujud nyata sasaran. Selfefficacy berhubungan dengan pertimbangan yang dibuat individu tentang kemampuannya dalam melaksanakan prilaku yang sesuai dengan tugas situasi atau tugas tertentu. Lebih lanjut Bandura (1994) menjelaskan bahwa self-efficacy adalah keyakinan terhadap kemampuan seseorang untuk mengatur dan melakukan suatu tindakan yang diperlukan untuk mengatur situasi yang prospektif. Dengan kata lain self-efficacy adalah keyakinan seseorang pada kemampuan dirinya untuk berhasil pada situasi tertentu. Bandura (1997) menjelaskan keyakinan ini sebagai penentu bagaimana seseorang berfikir, bertingkah laku, dan berperasaan. Sedangkan Schunk (1995) mengemukakan bahwa self-efficacy mempengaruhi siswa dalam proses seleksi aktivitasnya. Siswa dengan self-efficacy yang rendah mungkin akan menghindari pelajaran yang tugasnya lebih banyak, apalagi tugas yang menantang, sedangkan siswa dengan self-efficacy yang tinggi memiliki keinginan yang besar untuk sukses mengerjakan tugas-tugasnya.

Berdasarkan kepada uraian di atas, self-efficacy pada prinsipnya mengarah kepada keyakinan diri. Referensi dari self-efficacy adalah pada kekuatan keyakinan diri individu supaya mampu melakukan tugas atau kegiatan yang berpengaruh pada motivasi dan prestasinya.

\section{Dimensi Self-Efficacy}

Bandura (1997) mengemukakan bahwa self-efficacy individu dapat dilihat dari tiga dimensi, yaitu: tingkat (level), keluasan (generality), dan kekuatan (strength). Pertama adalah tingkat (level). Terkait dengan tingkat kesulitan tugas, ada perbedaan self-efficacy individu dalam mengerjakannya. Individu memiliki tingkat self-efficacy yang tinggi pada tugas yang mudah dan sederhana, atau juga pada tugas-tugas yang rumit dan membutuhkan kompetensi yang tinggi (Bandura, 1994). Individu yang memiliki tingkat self-efficacy tinggi cenderung memilih tugas yang kesukarannya selevel dengan kemampuan. Kedua adalah keluasan (generality). Dimensi ini terkait dengan penguasaan individu terhadap bidang atau tugas pekerjaan. Individu dapat menyatakan dirinya memiliki self-efficacy pada aktivitas yang luas, atau terbatas pada fungsi domain tertentu saja (Sopiyah, 2016)). Individu dengan self-efficacy yang tinggi akan mampu menguasai beberapa bidang sekaligus untuk menyelesaikan suatu tugas (Schunk, 1995). Individu yang memiliki selfefficacy yang rendah hanya menguasai sedikit bidang yang diperlukan dalam menyelesaikan suatu tugas. Ketiga adalah kekuatan (strength). Dimensi yang ketiga atau yang terakhir ini menekankan kemantapan individu terhadap keyakinannya. Self-efficacy menunjukkan bahwa tindakan yang dilakukan individu akan memberikan hasil sesuai dengan yang diharapkan individu. Self-efficacy adalah dasar sebelum dirinya melakukan usaha keras, bahkan ketika menemui hambatan.

\section{Faktor-faktor yang membentuk self-efficacy}

Bandura (1997) dan Alwisol (2010) menyatakan ada empat sumber dari selfefficacy, yaitu pengalaman kinerja, pengalaman orang lain, persuasi sosial, dan keadaan emosional. 
Pertama, tentang Pengalaman kinerja. Kesuksesan dan prestasi seseorang membuat semakin meningkatnya self-efficacy. Pengalaman kinerja adalah prestasi yang pernah diraihnya pada masa lalu. Kinerja yang dilakukan masa yang lalu menjadi faktor pengubah rasa percaya diri yang paling kuat. Kesuksesan akan memberi dampak pada self-efficacy yang berbeda-beda tergantung proses pencapaiannya. (a) Orang yang biasa berhasil, sekali-kali mengalami kegagalan tidak mempengaruhi self efficacy-nya. (b) Semakin sulit tugasnya, maka keberhasilan yang diraihnya akan membuat self-efficacy-nya semakin tinggi. (c) Kerja sendiri (secara mandiri) akan meningkatkan self-efficacy dibandingkan dengan kerja dibantu orang lain dan kerja kelompok. (d) Kegagalan dalam kondisi stress dampaknya tidak seburuk manakala kondisinya optimal. (e) Kegagalan pada orang yang telah memiliki self-efficacy yang kuat tidak seburuk yang dialami oleh orang yang keyakinan self-efficacy-nya belum kuat.

Kedua tentang pengalaman orang lain. Melalui model sosial pengalaman orang lain dapat diperoleh, sehingga self-efficacy dapat meningkat manakala individu mengamati orang lain yang kemampuannya setara. Feist \& Feist (2009) berpendapat ketika orang lain itu berbeda dari individu, maka dampak dari pengalaman orang lain akan memiliki efek self-efficacy yang tidak signifikan baginya. Secara umum dapat dikatakan bahwa performa pribadi meningkatkan selfefficacy yang lebih tinggi dibandingkan dengan dampak yang disebabkan oleh pengalaman orang lain. Namun pengalaman orang lain memiliki pengaruh yang kuat pada saat menunjukkan penurunan self-efficacy.

Ketiga tentang persuasi Sosial. Persuasi sosial menurut Bandura (dalam Feist \& Feist, 2009) dapat memperkuat atau melemahkan self-efficacy seseorang. Pengaruh dari sumber persuasi sosial terbatas, namun di bawah kondisi yang akurat dan tepat persuasi dari orang lain dapat meningkatkan atau menurunkan tingkat self-efficacy. Rasa percaya diri yang kuat terhadap pemberi persuasi menunjukkan kondisi yang tepat agar dapat meningkatkan self-efficacy.

Keempat adalah kondisi emosional. Perubahan tingkah laku dapat terjadi manakala sumber ekspektasi self-efficacy-nya berubah. Keadaan emosi yang mengikuti aktivitas suatu bidang mempengaruhi self-efficacy seseorang di bidang tersebut. Bisa jadi self-efficacy seseorang berkurang manakala terjadi emosi yang kuat, takut, cemas, atau stress. Perubahan self-efficacy dipakai untuk memperbaiki kesulitan dan adaptasi tingkah laku orang yang mengalami berbagai masalah prilaku. Menurut Trans Theoretical Model (Prochaska et al., 1992), self-efficacy dan hasil pemahaman positif ("pros") dan pemahaman negatif ("cons") dipandang sebagai variabel sosial kognitif yang berubah sepanjang waktu. Self-efficacy khususnya yang rendah akan meningkat ketika individu berpindah ke tingkatan yang lebih tinggi. Self-efficacy diserupakan dengan keyakinan diri siswa dalam melakukan dan melaksanakan usaha menyelesaikan tugas-tugas dan mencapai tujuan tertentu dalam mencerna dan mempelajari matematika.

\section{Self-Efficacy dan Pengaruhnya kepada Prestasi Akademik Matematika}

Self-efficacy merupakan keyakinan seseorang dari kemampuan mereka, dan telah terbukti mempengaruhi prestasi matematikasiswa (Bandura, Barbaranelli, Caprara \& Pastorelli, 1996; Pajares \& Miller 1995). Bandura et al. (1996) berpendapat bahwa self-efficacy dapat mempengaruhi banyak bagian dari kehidupan seseorang seperti "Tingkat motivasi dan ketekunan dalam menghadapi kesulitan dan 
kemunduran, ketahanan terhadap kesulitan, kualitas pemikiran analitis. Dari pendapat tersebut, jelas bahwa self-efficacy dibutuhkan dalam mempelajari matematika. Matematika bukanlah subjek mudah, sehingga kesulitan dan kemunduran sering terjadi, sehingga penting untuk memiliki motivasi, ketekunan, dan ketahanan untuk terus menunjukkan upaya di kelas matematika.

Konsekuensi psikologis dari lemahnya self-efficacy pada matematika adalah munculnya sikap negatif yang mengarah kepada motivasi yang rendah dan apatis terhadap pelajaran matematika. Weinstein (dalam Lusby, 2009) menemukan bahwa siswa yang merasa bosan dalam pelajaran matematika dan tidak menikmati kelas maka mereka cenderung memiliki perilaku yang mengabaikan atau menurut (hanya mengikuti yang ditugaskan oleh guru), yang keduanya dapat mempengaruhi produktivitas dan partisipasi di kelas.

\section{Karakteristik Pelajaran Matematika Sebagai Aktivitas Berfikir}

Matematika berkaitan erat dengan aktivitas dan proses belajar dan berpikir. Karakteristik matematika merupakan suatu ilmu dan human activity, yaitu matematika merupakan pola berpikir, pola mengorganisasi pembuktian yang logis, dengan menggunakan istilah yang didefinisikan secara cermat, jelas dan akurat (Sabandar, 2009). Oleh karena itu, tanpa meningkatkan dan mengandalkan pembelajaran matematika yang berkualitas yang menuntun siswa untuk berpikir, akan sangat sulit untuk dapat tercapai kemampuan berpikir agar menghasilkan sebuah hasil prestasi belajar matematika yang baik. Dalam belajar matematika, hal ini tentu bukan suatu hal yang sederhana. Aktivitas dan proses berpikir akan terjadi apabila seorang individu berhadapan dengan suatu situasi atau masalah yang mendesak dan menantang serta dapat memicunya untuk berpikir agar diperoleh kejelasan dan solusi atau jawaban terhadap masalah yang dimunculkan dalam situasi yang dihadapinya (Sabandar, 2009a).

Beberapa landasan pemikiran umum yang menerangkan pentingnya proses berpikir dalam pembelajaran matematika yang dijelaskan dalam Sabandar (2009) adalah: (a) terdapat tuntutan dalam kurikulum yang berlaku untuk dicapainya kemampuan berpikir kritis dan berpikir kreatif agar nantinya individu dapat menjawab tuntutan dalam rangka menyesuaikan diri dengan perkembangan peradaban, serta tuntutan dalam perbaharuan tentang standardisasi instrumeninstrumen tes yang mengukur kapasitas siswa secara aktif dalam mengaplikasikan pengetahuan; (b) terdapat perubahan pandangan mengenai tujuan pendidikan bahwa kemampuan berpikir harus menjadi tujuan yang penting dan utama dalam proses pembelajaran; (c) terdapat fakta yang memaparkan bahwa pembelajaran yang monoton dengan cara tradisional tidak dapat mengembangkan kemampuan berpikir siswa secara optimal, terdapatnya pandangan bahwa proses berpikir yang baik akan mengantarkan seseorang pada pemahaman yang lebih mendalam di berbagai disiplin ilmu, pandangan bahwa kecerdasan dapat dipelajari, sehingga tentu dapat pula diajarkan.

Selain alasan-alasan umum yang dikemukakan sebelumnya, secara khusus mengembangkan kemampuan berpikir mutlak diperlukan dalam kelas matematika karena matematika memiliki karakteristik sebagai suatu cabang ilmu yang objek kajiannya bersifat abstrak serta berkaitan dengan pola berpikir (Schoenfeld, 2016). Lebih lanjut, Schoenfeld (2016) menyatakan bahwa matematika bukan hanya sekumpulan rumus atau kegiatan berhitung semata, tetapi juga merupakan suatu 
ilmu yang objek kajiannya berupa ide-ide, gagasan-gagasan serta konsep yang abstrak serta hubungan-hubungannya, yang pengembangannya terangkai dalam suatu proses yang terstruktur dan logis dengan menggunakan istilah-istilah dan simbol-simbol khusus.

Dengan karakteristik seperti ini suatu konsep matematika harus dikenalkan kepada siswa melalui serangkaian proses berpikir, dan bukan dikenalkan sebagai suatu produk jadi (Sabandar, 2009). Oleh karena itu, kemampuan berpikir perlu dikembangkan dalam proses pembelajaran matematika. Diharapkan kepada siswa yang telah belajar matematika supaya mereka bukan hanya mampu menghafal rumus dan prosedur untuk menyelesaikan soal-soal saja namun memiliki pemahaman dan kemampuan berpikir yang logis dan baik yang terintegrasi atau menyatu menjadi bagian dalam diri siswa itu sendiri dan kelak dapat berguna untuk menyelesaikan berbagai masalah dalam kehidupan.

\section{CBT untuk Meningkatkan Self-Effiacy siswa pada Pelajaran Metematika}

Menurut teori kognitif sosial Bandura (1994), self-efficacy mempengaruhi pilihan orang dalam membuat dan menjalankan tindakan yang mereka kejar. Individu cenderung berkonsentrasi dalam tugas- tugas yang mereka rasakan mampu dan percaya dapat menyelesaikannya serta menghindari tugas-tugas yang tidak dapat mereka kerjakan.Merubah self-efficacy berarti merubah pola pikir, dan jenis konseling yang dapat dilakukan adalah konseling kognitif-perilaku, atau yang biasa dikenal dengan istilah CBT. Bush (2003) menyatakan bahwa CBT merupakan perpaduan antara dua pembekalan yaitu terapi kognitif dan terapi behavioral. Terapi kognitif diasumsikan pada pikiran dan kepercayaan (efikasi diri), sedangkan terapi tingkah laku membantu untuk membangun hubungan antara solusi permasalahan dengan kebiasaan mereaksi permasalahan.

Kumar \& Sebastian (2011) menguji efektivitas dari CBT pada self-efficacy dan prestasi akademik remaja. Sampel sebanyak 200 remaja (100 dieksperimental dan 100 pada kelompok kontrol) yang mendapatkan skor rendah pada skala self-efficacy umum (GSE) dan nilai rendah pertama dari dua ujian harian mereka. Kelompok eksperimen menerima 12 sesi terapi kognitif perilaku. Hasil penelitian tersebut mengungkapkan bahwa kelompok eksperimen menunjukkan peningkatan yang signifikan dalam self-efficacy mereka dan prestasi akademik.

Self-efficacy memiliki korelasi dengan strategi CBT dalam mengubah pikiran individu, perilaku, emosi, dan prestasi individu (Bandura, 1997). Intervensi perilaku kognitifdi SMA akan membantu siswa menyadari tiga hal: a) pola pikir yang mempengaruhi perilaku mereka; b) cara mereka bias mengendalikan pola pikir, dan c) cara mengaplikasikan langkah langkah intervensi untuk merubah perilaku. (Hall \&Hughes, 1989) pengalaman pada sesi konseling memberikan kesempatan kepada siswa untuk tidak menghindari masalah melainkan memikirkan cara yang mampu dilakukannya untuk menyelesaikan masalah tersebut, sehingga muncul keyakinan pada diri akan kemampuannya menyelesaikan permasalahan.

\section{METODE PENELITIAN}

Penelitian dilakukan di salah satu SMA Negeri di Kota Bandung, Jawa Barat. Langkah-langkah implementasi konseling cognitive behavioral untuk meningkatkan self-eficacy terhadap pelajaran matematika. Pelaksanaan penelitian dilakukan melalui beberapa tahapan sebagai berikut: (a) pelaksanaan pre-test di 
Salah satu SMA tempat penelitian di Bandung untuk mengetahui profil kategori self-efficacy terhadap pelajaran matematika; (b) penentuan sampel siswa yang mengalami kesulitan belajar, atau hambatan akademik; (c) pelaksanan Baseline-1 untuk mengkonfirmasi kestabilan kondisi self-efficacy siswa tehadap pelajaran matematika pada kategori sangat rendah; (d) pelaksanaan intervensi teknik konseling cognitive behavioral untuk meningkatkan self-efficacy terhadap pelajaran matematika selama enam sesi; (e) penyajian laporan tentang pelaksanaan teknik konseling cognitive behavioral dalam meningkatkan self-efficacy terhadap pelajaran matematika.

Subjek dalam penelitian ini adalah siswa kelas XI bidang Matematika dan Ilmu Alam, dari penyebaran inventori terdapat 3 siswa yang memiliki skor self-efficacy rendah dan dijadikan sebagai subjek penelitian. Pertama Konseli RW (nama samaran), memiliki tingkat self efficacy rendah. Tingkat self-efficacy terhadap pelajaran matematika yang dialami oleh RW berdasarkan inventori self-efficacy rendah dengan rata-rata skor sebesar 8,3. Base line self-efficacy dimuat pada Gambar 1.

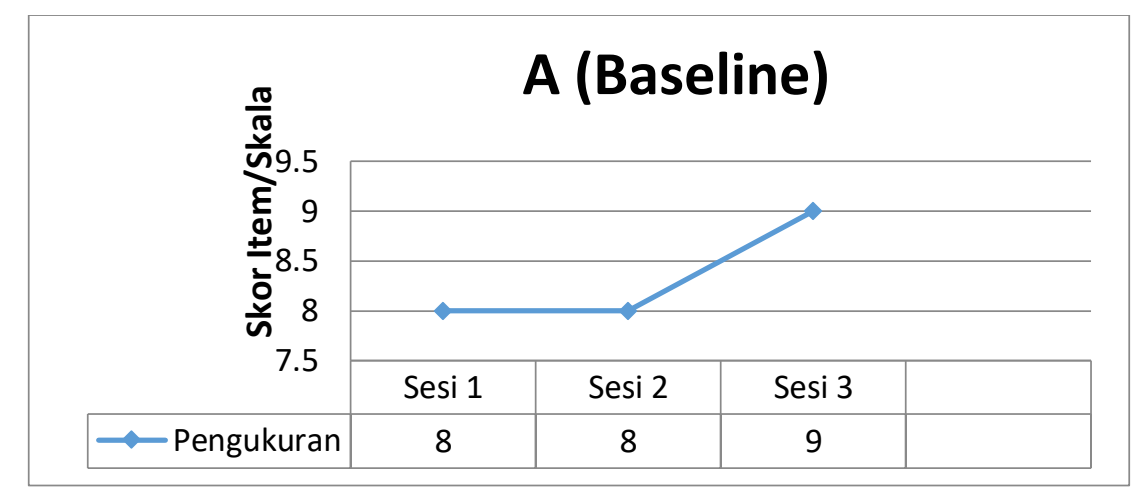

Gambar 1. Baseline Konseli RW Sebelum Mendapatkan Intervensi

Selain keterangan data dari inventori self-efficacy, berdasarkan deskripsi hasil pemerikasaan psikotes, konseli RW memiliki skor IQ dengan kualifikasi di atas rata-rata, dan bakat dalam bidang matematika menunjukkan tingkat potensi yang sedang. Selain itu berdasarkan studi penelusuran riwayat pendidikan di SMP dalam pelajaran matematika menunjukan bahwa RW memiliki nilai matematika yang sedang. Saat berada di kelas X, dengan berbagai data dan pertimbangan, sekolah memasukkan RW pada program IIS, kemudian di kelas XI atas keinginan dirinya dan harapan orangtuanya, ia dipindahkan di program MIA. Saat di program MIA, RW mulai mengalami kesulitan dalam mata pelajaran matematika. Berdasarkan hasil wawancara dengan konseli diketahui bahwa, RW merasa tertinggal dengan teman-temannya dalam pelajaran matematika, dan lambat berfikir dalam soal hitungan, hal tersebut semakin membuat RW merasa tidak ada lagi motivasi untuk mempelajari pelajaran matematika.

Kedua, konseli AL memiliki tingkat self-efficacy dalam pelajaran matematika yang rendah dengan rata-rata skorsebesar 8,6. Baseline self-efficacy digambarkan pada gambar 2.

Dari sumber data yang sama dari inventori self-efficacy, dan hasil pemeriksaan psikotes, konseli AL memiliki skor IQ dengan kualifikasi sangat cerdas, dan bakat dalam bidang matematika menunjukkan tingkat potensi yang sedang. Berdasarkan 
hasil wawancara dengan konseli diketahui bahwa, AL kurang memiliki minat dalam mata pelajaran matematika, dan merasa tidak punya banyak waktu untuk mempelajari dan mengerjakan PR matematika. Selain itu berdasarkan studi penelusuran riwayat pendidikan di SMP dalam pelajaran matematika menunjukkan bahwa AL memiliki nilai matematika yang rendah, dan tidak menyukai matematika sejak di bangku SMP kelas 1. AL masuk ke SMA tempat penelitian ini melalui jalur prestasi renang, dan dirinya lebih banyak meluangkan waktu untuk latihan renang dari pada mempelajari matematika, bahkan ia malas untuk mempelajari matematika. Dirinya berpersepsi bahwa matematika tidak ada hubungannya dengan aktivitas renang, sehingga cenderung mengabaikan pelajaran matematika dan ia lebih mementingkan latihan renang.

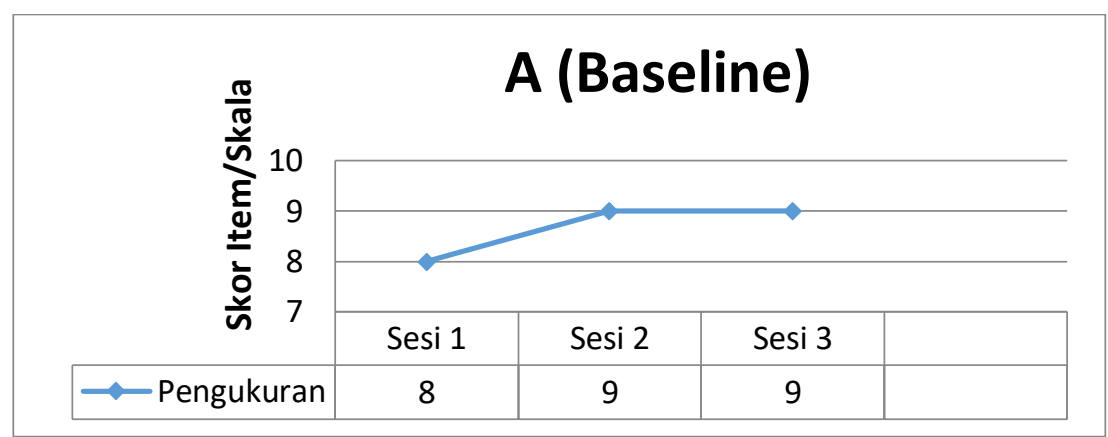

Gambar 2. Baseline Konseli ALSebelum Mendapatkan Intervensi

Selanjutnya konseli yang ketiga, RN memiliki Tingkat self-efficacy yang rendah dengan rata-rata skor sebesar 8,3. Baseline self-efficacy digambarkan pada Gambar 3 .

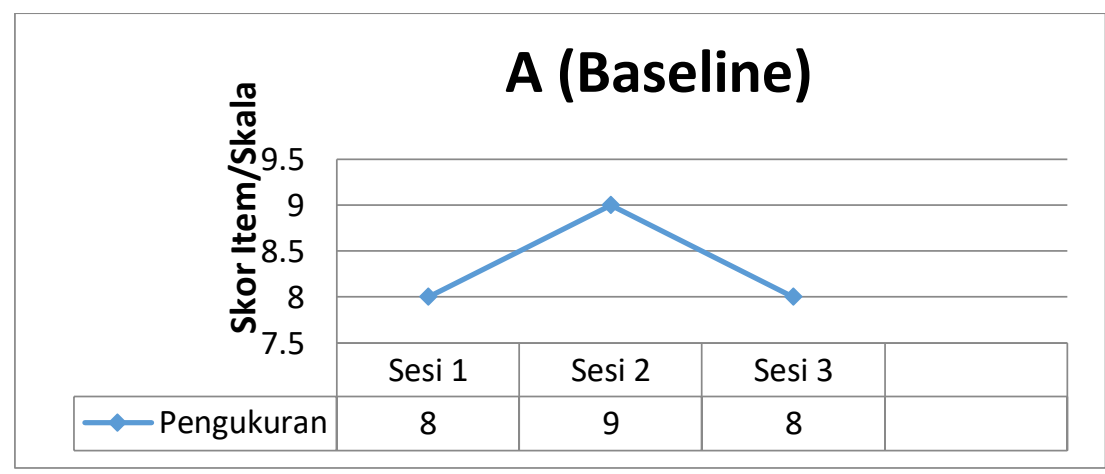

Gambar 3. Baseline Konseli RNSebelum Mendapatkan Intervensi

Selain keterangan data dari inventori self-efficacy, berdasarkan deskripsi hasil pemerikasaan psikotes, konseli RN memiliki skor IQ dengan kualifikasi sangat cerdas, dan bakat dalam bidang matematika menunjukkan tingkat potensi yang sedang. Berdasarkan hasil wawancara dengan konseli diketahui bahwa, RN kurang mampu dalam menghafal dan memahami rumus-rumus pelajaran matematika, merasa kurang mampu mempelajari matematika, dan tidak ada usaha untuk mempelajari matematika. Selain itu berdasarkan studi penelusuran riwayat pendidikan di SMP dalam pelajaran matematika menunjukkan bahwa RN memiliki nilai matematika yang sedang, dan tidak menyukai matematika sejak di bangku SMP kelas dua. 


\section{Pelaksanaan Konseling Cognitive Behavioral}

Pelaksanaan intervensi melalui konseling cognitive behavioral untuk meningkatkan self-efficacy siswa terhadap pelajaran matematika, dilaksanakan selama satu kali dalam seminggu namun tetap menyesuaikan dengan fleksibilitas waktu dari konseli. Kemudian diberikan homework sebagai intervensi perilaku. Jadwal sesi konseling untuk masing-masing konseli disajikan dalam Tabel 1.

Tabel 1. Jadwal pelaksanaan Konseling

\begin{tabular}{lll}
\hline Subjek Penelitian & Jadwal Pelaksanaan Konseling & Tempat Pelaksanaan \\
\hline \multirow{2}{*}{ RW } & 14 Januari 2015 (Sesi 1) & \\
& 21 Januari 2015 (Sesi 2) & Ruang BK \\
& 02 Februari 2015 (Sesi 3) & \\
\multirow{3}{*}{ AL } & 16 Januari 2015 (Sesi 1) & Ruang BK \\
& 23 Januari 2015 (Sesi 2) & \\
\hline \multirow{3}{*}{ O6 Januari 2015 (Sesi 3) } & 20 Januari 2015 (Sesi 1) & \\
& 27 Januari 2015 (Sesi 2) & Ruang BK \\
\hline
\end{tabular}

Deskripsi proses pelaksanaan kegiatan intervensi melalui konseling cognitive behavioral untuk meningkatkan self-efficacy siswa terhadap pelajaran matematika pada setiap konseli dipaparkan dan dijelaskan pada hasil penelitian.

\section{HASIL DAN PEMBAHASAN}

Self-efficacy siswa terhadap pelajaran matematika merupakan aspek pribadi yang memerlukan intervensi terencana agar dapat secara efektif meningkatkan kesiapan siswa dalam menghadapi berbagai tuntutan dan tugas pada pelajaran matematika. Matematika merupakan ilmu universal yang mendasari perkembangan teknologi modern. Mata pelajaran matematika merupakan pengetahuan dasar, dan kompetensi penunjang untuk mata pelajaran lainnya yang perlu dikuasai oleh siswa.

Hasil penyebaran instrumen self-efficacy siswa terhadap pelajaran matematika, pada 173 siswa kelas XI MIA 8,2,1,6, dan 5 yang secara administratif terdaftar di SMA tempat penelitian memberikan fakta empiris mengenai profil self-efficacy siswa terhadap pelajaran matematika sebagai berikut: (a) siswa yang termasuk pada kategori tinggi berjumlah 34 orang atau 19,8\%; (b) kategori sedang sejumlah 108 orang atau 62,8\%; (c) ada kategori rendah sejumlah 25 orang atau sekitar 14,5\%; (d) pada kategori sangat rendah sejumlah 5 orang atau sekitar 2,9\% .

Selain itu, hasil pretes menunjukkan bahwa aspek terendah dalam kelompok populasi adalah pada aspek level pada item dapat mempelajari matematika hingga yang paling sulit yang diajarkan di kelas sebanyak 27\%; kemudian pada aspek generality sebesar $26 \%$ dengan item jarang mengalami kesulitan dalam menghadapi ulangan matematika, karena telah melakukan latihan soal sebelumnya; $30 \%$ pada aspek strength, yaitu pada item melakukan latihan soal untuk memperdalam konsep matematika, daripada bermain dengan teman teman.

Self-efficacy yang rendah terhadap pelajaran matematika akan mengakibatkan kesulitan belajar dan mengganggu performa akademik siswa dalam pelajaran 
matematika. Self-efficacy merupakan salah satu potensi yang ada pada factor kognitif manusia, self-efficacy ini berpengaruh besar terhadap perilaku manusia. Rancangan intervensi yang dapat mengubah pemikiran terhadap pelajaran matematika dengan berbagai tuntutannya perlu dilakukan, sehingga dapat memunculkan perilaku yang dapat mendukung performa akademik yang baik dalam pelajaran matematika.

Strategi CBT berkorelasi dengan pengembangan self-effiacy dalam mengubah pikiran individu, perilaku, emosi, dan prestasi individu (Bandura, 1997). Intervensi perilaku kognitif di SMA akan membantu siswa menyadari tiga hal: a.) pola piker yang mempengaruhi perilaku mereka; b.) cara mereka bisa mengendalikan pola pikir, dan c.) cara mengaplikasikan langkah-langkah intervensi untuk mengubah perilaku (Hall \& Hughes, 1989). Pengalaman pada sesi konseling memberikan kesempatan kepada siswa untuk tidak menghindari masalah melainkan memikirkan cara yang mampu dilakukannya untuk menyelesaikan masalah tersebut, sehingga muncul keyakinan pada diri akan kemampuannya menyelesaikan permasalahan.

Kumar \& Sebastian (2011: 134) menguji efektivitas dari CBT pada self-efficacy dan prestasi akademik remaja. Sampel terdiri dari 200 remaja (100 pada kelompok eksperimen dan 100 pada kelompok kontrol) yang mendapatkan skor rendah pada skala self-efficacy umum (GSE) dan nilai rendah pertama dari dua ujian harian mereka. Kelompok eksperimen menerima 12 sesi terapi kognitif perilaku. Hasil penelitian tersebut mengungkapkan bahwa kelompok eksperimen menunjukkan peningkatan yang signifikan dalam self-efficacy mereka dan prestasi akademik. Oleh karena itu, disusunlah rancangan intervensi konseling cognitive behavioral untuk meningkatkan self-efficacy siswa pada mata pelajaran matematika.

\section{Sasaran intervensi}

Dari 173 responden di SMA tempat penelitian dalam tahun ajaran 2014/2015, dilakukan intervensi terhadap lima orang siswa dengan profil self-efficacy sangat rendah, stabil pada kondisi baseline, dan menyatakan bersedia mengikuti konseling dengan peneliti.

1. Sesi intervensi

Intervensi teknik konseling cognitive behavioral dalam meningkatkan self-efficacy siswa pada pelajaran matematika dilakukan selama enam sesi. Sesi intervensi yang dirancang berdasarkan hasil pertimbangan profil kognitif dan self-efficacy yang dimiliki siswa, dan penyesuaian penerapan konseling cognitive behavioral dalam adegan persekolahan. Penentuan jadwal intervensi berdasarkan kesepakatan antara konselor dan konseli. Setiap konseli memasuki sesi konseling setelah melewati tahap awal yang meliputi kontrak konseling dan diagnosis kognitif secara umum, kemudian dilanjutkan dengan sesi lanjutan yang berfokus mengembangkan pemikiran-pemikiran yang mampu meningkatkan self-efficacy siswa terhadap pelajaran matematika. Setiap sesi konseling menggunakan teknik-teknik berikut: (a) menata keyakinan irasional; (b) bibliotherapy, menerima kondisi emosional internal sebagai sesuatu yang menarik ketimbang sesuatu yang menakutkan; (c) mengulang kembali penggunaan beragam pernyataan diri dalam role play dengan konselor; (d) mencoba penggunaan berbagai pernyataan diri yang berbeda dalam situasi riil; (e) mengukur perasaan, misalnya dengan mengukur perasaan cemas yang dialami pada saat ini dengan skala 0-100; (f) menghentikan pikiran negatif, yaitu konseli belajar untuk menghentikan pikiran negatif dan mengubahnya 
menjadi pikiran positif; (g) desensitization systematic, digantinya respons takut dan cemas dengan respon relaksasi dengan cara mengemukakan permasalahan secara berulang-ulang dan berurutan dari respon takut terberat sampai yang teringan untuk mengurangi intensitas emosional konseli; (h) pelatihan keterampilan sosial, yaitu melatih konseli untuk dapat menyesuaikan dirinya dengan lingkungan sosialnya; (i) assertiveness skill training atau pelatihan keterampilan supaya bisa bertindak tegas.; (j) penugasan rumah dengan cara mempraktikan perilaku baru dan strategi kognitif antara sesi konseling; (k) in vivo exposure, yaitu mengatasi situasi yang menyebabkan masalah dengan memasuki situasi tersebut; (l) covert conditioning, upaya pengkondisian tersembunyi dengan menekankan kepada proses psikologis yang terjadi di dalam diri individu di mana peranannya di dalam mengontrol perilaku berdasarkan kepada imajinasi, perasaan dan persepsi.

\section{Indikator keberhasilan}

Evaluasi keberhasilan intervensi cognitive behavioral dilakukan pada setiap sesi intervensi dan setelah seluruh program intervensi selesai dilaksanakan. Siswa yang berhasil mengikuti kegiatan intervensi adalah siswa yang mampu memiliki pemikiran pemikiran yang positif terhadap dirinya dan pelajaran matematika, sehingga berpengaruh kepada peningkatan self-efficacy terhadap pelajaran matematika. Salah satu sumber evaluasi penelitian ini adalah analisis terhadap catatan proses konseling, dan gain antara kondisi baseline dan pasca intervensi. Indikator keberhasilah intervensi secara keseluruhan ditunjukkan oleh perubahan perilaku siswa berupa upaya untuk mempelajari dan mengerjakan tugas-tugas pada mata pelajaran matematika. Hal ini dapat dilakukan dengan cara mengamati perilaku siswa di sekolah dan di kelas berkolaborasi dengan wali kelas serta konselor sekolah.

\section{Deskripsi pelaksanaan konseli RW}

Berikut disajikan rangkuman dan penjelasan konseling RW pada setiap sesi yang dimuat dalam Tabel 2.

Tabel 2. Rangkuman dan penjelasan konseling RW pada setiap sesi

\begin{tabular}{lll}
\hline K \& & \multicolumn{1}{c}{ Percakapan } & \multicolumn{1}{c}{ Keterangan } \\
RW & \multicolumn{1}{c}{ Sesi I } & \\
\hline K & $\begin{array}{l}\text { Bagaimana pandangan RW tentang pelajaran matematika, sehingga } \\
\text { kamu kurang yakin kalau kamu mampu? }\end{array}$ & $\begin{array}{l}\text { Mengidentifikasi } \\
\text { pemikiran yang } \\
\text { berpengaruh } \\
\text { pada keyakinan }\end{array}$ \\
\hline RW & $\begin{array}{l}\text { Matematikan adalah pelajaran yang paling sulit, apalagi saya kalau } \\
\text { belajar matematika musti pelan-pelan, tidak bisa cepat-cepat. } \\
\\
\text { Teman-teman di kelas semuanya pandai dalam matematika, hanya } \\
\text { saya sendiri yang lambat dalam hitungan. Contohnya jika guru } \\
\text { memberikan soal 1 saja, saya mengerjakannya lama banget, padahal } \\
\text { teman-teman sudah selesai semuanya, itu karena saya lambat dalam } \\
\text { menghitung. }\end{array}$ \\
\hline K & $\begin{array}{l}\text { Mengapa RW beranggapan bahwa teman-teman lebih pandai dari } \\
\text { pada RW? }\end{array}$ & \\
\hline RW & $\begin{array}{l}\text { Kalau ulangan, teman-teman selalu dapat nilai bagus, sementara } \\
\text { saya selalu di bawah KKM, karena selain saya lambat dalam } \\
\text { menghitung, saya juga kurang mengerti penjelasan dari Guru, } \\
\text { sehingga waktu ulangan terkadang habis tanpa ada hasil, jadi ujung- }\end{array}$ \\
\hline
\end{tabular}


115| Sopiyah, Nurikhsan, Hafina, Efektivitas Teknik Konseling Cognitive Behavioral untuk...

\begin{tabular}{|c|c|c|}
\hline & $\begin{array}{l}\text { ujungnya saya nyontek kepada teman, agar lembar jawabannya tidak } \\
\text { kosong. }\end{array}$ & \\
\hline K & Apa yang membuat kamu berbeda dengan temanmu? & \\
\hline RW & $\begin{array}{l}\text { Guru menjelaskan terlalu cepat, sehingga saya tidak mengerti pada } \\
\text { saat mengerjakan soal-soal matematika. }\end{array}$ & \\
\hline $\mathrm{K}$ & $\begin{array}{l}\text { Mengapa teman-teman kamu baik-baik saja dengan cara gurumu } \\
\text { mengajar? }\end{array}$ & \multirow{4}{*}{$\begin{array}{l}\text { Mengkonfrontasi } \\
\text { untuk menata } \\
\text { keyakinan }\end{array}$} \\
\hline RW & $\begin{array}{l}\text { Masalahnya Saya lemah dan lambat dalam menghitung, sehingga } \\
\text { selalu ketinggalan dengan teman-teman. }\end{array}$ & \\
\hline K & $\begin{array}{l}\text { Baik, jadi permasalahannya kamu tidak siap pada pelajaran } \\
\text { matematika karena kamu lemah dan lambat dalam menghitung, dan } \\
\text { tidak bisa mengandalkan hanya dari pertemuan dengan guru di } \\
\text { kelas? }\end{array}$ & \\
\hline RW & Ia bu, saya lambat dan sulit mengikuti cara guru mengajar & \\
\hline $\mathrm{K}$ & $\begin{array}{l}\text { Mari kita fokuskan, kamu berfikir kamu memiliki keterbatasan } \\
\text { dalam mengikuti pembelajaran matematika di kelas, dan terbatas } \\
\text { dalam hitung hitungan, sehingga perlu upaya lain yang dapat } \\
\text { dilakukan di luar pertemuan di kelas, terimakasih sudah bersedia } \\
\text { hadir di sini, kita ketemu besok untuk melanjutkan sesi. }\end{array}$ & $\begin{array}{l}\text { Memfokuskan } \\
\text { masalah }\end{array}$ \\
\hline \multicolumn{3}{|c|}{ SESI II } \\
\hline $\begin{array}{l}\mathrm{K} \\
\& \mathrm{RW}\end{array}$ & Percakapan & Keterangan \\
\hline $\mathrm{K}$ & $\begin{array}{l}\text { Sesuai dengan hasil pertemuan kemarin bahwa kamu perlu } \\
\text { melakukan upaya di luar belajar di kelas untuk dapat meningkatkan } \\
\text { kemampuanmu dalam matematika, ibu sudah siapkan format yang } \\
\text { harus kamu isi mengenai keterbatasan kamu dalam matematika dan } \\
\text { upaya yang menurut kamu dapat kamu lakukan }\end{array}$ & \multirow[t]{4}{*}{$\begin{array}{l}\text { Bersama sama } \\
\text { merancang } \\
\text { upaya perubahan }\end{array}$} \\
\hline RW & (mengisi format yang disediakan) & \\
\hline $\mathrm{K}$ & Membahas pilihan pilihan RW: & \\
\hline$\& \mathrm{RW}$ & $\begin{array}{l}\text { 1. Les private } \\
\text { 2. Latihan mandiri penyelesaian soal di rumah, agar terlatih untuk } \\
\text { menghitung dan terbiasa menyelesaikan soal }\end{array}$ & \\
\hline $\mathrm{K}$ & $\begin{array}{l}\text { Baik kita bertemu lagi pada sesi selanjutnya untuk mengevaluasi } \\
\text { perubahan yang kamu dapatkan dari menjalankan rencana yang } \\
\text { sudah kamu tulis tadi }\end{array}$ & $\begin{array}{l}\text { Intervensi } \\
\text { Perilaku } \\
(\text { Homework })\end{array}$ \\
\hline \multicolumn{3}{|c|}{$\begin{array}{ll}\text { SESI III } \\
\end{array}$} \\
\hline K & $\begin{array}{l}\text { Selama tiga minggu ini dari rencana yang sudah dibuat sebelumnya } \\
\text { apa saja yang sudah terlaksana, dan belum, atau apakah RW } \\
\text { menghadapi hambatan? }\end{array}$ & \multirow[t]{4}{*}{$\begin{array}{l}\text { Evaluasi dan } \\
\text { Pencegahan }\end{array}$} \\
\hline RW & $\begin{array}{l}\text { Les private telah saya lakukan dan Saya sudah coba berlatih } \\
\text { mengerjakan latihan dari buku buku soal dan konsultasi pada guru } \\
\text { private }\end{array}$ & \\
\hline $\mathrm{K}$ & $\begin{array}{l}\text { Apakah kamu berfikir kalau cara ini sesuai dan dapat membantu } \\
\text { kamu lebih siap dengan matematika? }\end{array}$ & \\
\hline RW & $\begin{array}{l}\text { Saya fikir cara ini cocok, dan masih harus terus dicoba, soalnya } \\
\text { lesnya enam bulan }\end{array}$ & \\
\hline K & $\begin{array}{l}\text { Bagus teruskan usahanya, dan menurutmu dengan pola apakah kamu } \\
\text { akan lebih siap belajar matematika? Sebutkan contoh kesiapan } \\
\text { kamu! }\end{array}$ & \multirow[t]{2}{*}{$\begin{array}{l}\text { Penutupan Sesi } \\
\text { dan Refleksi } \\
\text { Keyakinan Baru }\end{array}$} \\
\hline RW & (sesuaikan dengan hasil angket) & \\
\hline
\end{tabular}

Berdasarkan Tabel 2, ada tiga sesi konseli yang dilakukan pada RW. Untuk penjelasan setiap sesinya adalah sebagai berikut.

a. Sesi 1

RW adalah seorang siswa di tempat peneliti bekerja, sehingga telah terjalin sebuah hubungan sebagai guru dan siswa sebelumnya. Sehingga dalam proses pembukaan 
konseling tidak mengalami permasalahan, terlihat RW dengan mudah menunjukkan sikap keterbukaannya dengan peneliti. Peneliti kembali kepada fokus sesi pertama setelah RW menunjukkan keterbukaan menjalani komunikasi dengan Peneliti. Peneliti mengkonfirmasi hasil skor pengukuran melalui inventori skala self-efficacy kepada Konseli RW terkait permasalahannya terhadap pelajaran matematika. RW membenar-kan bahwa ia mengalami permasalahan dalam pelajaran matematika dengan pernyataan "Matematika adalah pelajaran yang paling sulit, apalagi saya kalau belajar matematika harus pelan-pelan, tidak bisa cepat-cepat". Konfirmasi konseli direspon oleh Konselor dengan proses penyampaian esensi dari pertemuan pertama dengan Konseli RW.

Konselor menyatakan diri sebagai pihak yang akan melangsungkan konseling dengan RW. Konselor memberikan penjelasan mengenai tujuan umum konseling, yakni memfasilitasi konseli untuk mengatasi permasalahannya dalam pelajaran matematika. Kemudian menjelaskan prosedur konseling yang akan berlangsung selama tiga sesi dengan frekuensi pertemuan satu minggu sekali. Selanjutnya, memasuki tahap inti, pada tahap ini beberapa poin penting yang disampaikan oleh RW yaitu; bahwa RW merasa teman-teman di kelas semuanya pandai dalam matematika, dan hanya saya sendiri yang lambat dalam hitungan, kurang mengerti penjelasan dari Guru, dan menurutnya cara guru menjelaskan materi pelajaran matematika terlalu cepat, sehingga RW tidak mengerti dan mengalami kesulitan pada saat mengerjakan soal-soal matematika. Atas dasar pernyataan yang telah diungkapkan oleh RW, dapat diketahui bahwa RW mengalami indikasi-indikasi self-efficacy yang rendah terhadap mata pelajaran matematika. Terlihat pada pernyataan ketidak-berdayaannya terhadap pelajaran matematika.

Setelah RW menceritakan berbagai macam permasalahan terhadap pelajaran matematika, tahap selanjutnya yang dilakukan peneliti adalah berusaha membantu RW merekonstruksi kognitifnya dengan pertanyaan "Mengapa teman-teman kamu baik-baik saja dengan cara gurumu mengajar?" RW memberi respon dengan mengatakan "Masalahnya saya lemah dan lambat dalam menghitung, sehingga selalu ketinggalan dengan teman-teman". Ketertinggalan dan lambatnya RW dalam mengerjakan soal matematika menjadikan dirinya merasa tidak pandai, lemah dan lambat dalam pelajaran matematika. Keyakinan yang telah tertanam dalam diri RW terhadap matematika menjadikan persepsi dan daya kognitif RW lemah terhadap pelajaran matematika, sehingga memunculkan perilaku negatif terhadap matematika.

Peneliti kemudian memberikan penguatan terhadap kognitif RW dengan melakukan klarifikasi "Jadi permasalahannya kamu tidak siap pada pelajaran matematika karena kamu lemah dan lambat dalam menghitung, dan tidak bisa mengandalkan hanya dari pertemuan dengan guru di kelas?". RW kemudian mengiyakan pertanyaan peneliti, sehingga peneliti mengajak RW untuk memikirkan sebuah upaya lain yang dapat dilakukan di luar pertemuan di kelas untuk meningkatkan kemampuan RW dalam pelajaran matematika. Hal tersebut peneliti lakukan agar RW menyadari bahwa kelemahan dan lambat dalam menghitung disebabkan oleh dirinya yang malas belajar matematika, sehingga dirinya tertinggal oleh teman-temannya saat mengerjakan matematika, bukan factor potensi matematikanya yang rendah. 


\section{b. Sesi 2}

Sesi 2 dimulai dengan aktifitas dialog ringan, yaitu saling memberi salam dan bertanya kabar, serta bertanya kepada RW tentang persepsinya terhadap pelajaran matematika. Selanjutnya peneliti masuk pada tahap inti dengan mengatakan "Sesuai dengan hasil pertemuan kemarin bahwa kamu perlu melakukan upaya di luar belajar di kelas untuk dapat meningkatkan kemampuanmu dalam matematika, Ibu sudah siapkan format yang harus kamu isi mengenai keterbatasan kamu dalam matematika dan upaya yang menurut kamu dapat kamu lakukan”. Kemudian peneliti dan RW membahas tentang pilihan apa yang akan dilakukan RW untuk mengatasi kelemahannya dalam pelajaran matematika. RW kemudian menyimpulkan dan memilih untuk melakukan les private, dan latihan mandiri penyelesaian soal di rumah. Upaya tersebut dilakukan agar RW terlatih untuk menghitung dan terbiasa menyelesaikan soal-soal matematika. Sesi ke 2 peneliti akhiri dengan mengatakan kepada RW untuk bertemu kembali pada sesi selanjutnya untuk mengevaluasi perubahan dan apa yang telah RW dapatkan dari rencana yang telah dibuat.

\section{c. Sesi 3}

Sesi 3 dimulai dengan salam dan penjelasan tujuan dari sesi ketiga, yaitu mengidentifikasi keberhasilan tindakan yang sudah dilakukan selama dua minggu. Pada sesi ketiga ini pula, peneliti menanyakan perubahan yang dirasakan oleh RW setelah mengalami dua sesi konselingsebelumnya. Selanjutnya peneliti bertanya kepada RW tentang rencana yang telah dibuat pada sesi konseling kedua, "Selama tiga minggu ini dari rencana yang sudah dibuat sebelumnya apa saja yang sudah terlaksana, dan belum, atau apakah RW menghadapi hambatan?". Pertanyaan tersebut merupakan sebuah bentuk evaluasi terhadap rencana kegiatan yang telah dibuah oleh RW apakah telah direalisasikan atau belum. RW memberikan respon dengan mengatakan "Les private telah saya lakukan dan Saya sudah coba berlatih mengerjakan latihan dari buku-buku soal dan konsultasi pada guru private”. Peneliti kemudian menanyakan apakah cara tersebut menjadikan RW lebih siap dan lebih yakin dalam mengerjakan dan mempelajari matematika, RW memberikan respon bahwa ia merasa cara tersebut cocok, dan masih terus akan dicoba. Sesi ke tiga ini peneliti tutup dengan memberikan penguatan kepada RW untuk meneruskan usahanya dalam mengatasi permasalahannya dalam pelajaran matematika. Untuk konseli AL dan RN hanya dikemukakan sesi sesi terakhir saja sehubungan keterbatasan ruang dalam jurnal ini.

Sesi 3 untul AL dimulai dengan salam dan penjelasan tujuan dari sesi ketiga yang merupakan sesi terakhir, yaitu mengidentifikasi keberhasilan tindakan yang sudah dilakukan AL selama dua minggu. Pada sesi ketiga ini pula, peneliti menanyakan perubahan yang dirasakan oleh AL terhadap pelajaran matematika setelah mengalami dua sesi konseling sebelumnya. Selanjutnya peneliti mengajak AL mengevaluasi rencana yang telah dibuat pada sesi konseling kedua "Dengan melakukan time schedule untuk belajar matematika, apakah kamu berfikir kalau kamu bisa lebih yakin dan siap pada pelajaran matematika?" AL memberikan jawaban bahwa ia lebih yakin dan lebih siap dalam mempelajari dan mengerjakan matematika. Sesi ke-3 ini peneliti tutup dengan memberikan apresiasi kepada ALatas perubahan positif yang telah ia lakukan, dan dukungan untuk meneruskan usahanya dalam mengatasi permasalahannya dalam pelajaran matematika. 
Dalam sesi terakhir konseli RN, peneliti mengajak RN untuk menceritakan perkembangan yang didapat terhadap pelajaran matematika, RN memberikan informasi bahwa dirinya merasa mendapatkan banyak pengalaman belajar baru terhadap matematika, pengalaman baru tersebut didapatkan dari usahanya belajar sendiri, dari teman dan guru, dan dirinya merasa yakin dapat mengerjakan soal matematika sendiri, serta berusaha untuk terus belajar agar tidak tertinggal dengan teman-temannya. Sesi ke tiga ini peneliti tutup dengan memberikan dukungan kepada RN agar terus mempertahankan keyakinan dan semangatnya terhadap pelajaran matematika.

\section{Efektivitas Konseling Cognitive Behavioral untuk Meningkatkan Self-Efficacy SiswaTerhadap Pelajaran Matematika}

Pengujian efektivitas konseling cognitive behavioral untuk meningkatkan selfefficacy siswa terhadap pelajaran matematika dilakukan untuk melihat gambaran dari keberhasilan konseling yang telah dilaksanakan. Gambaran hasil konseling disajikan sebagai berikut.

1. Analisis hasil konseli RW setelah intervensi

Konseli RW berpartisipasi selama tiga sesikonseling dan tiga sesi pengukuran. Grafik hasil pengukuran antara baseline dan intervensi disajikan pada Gambar 4 berikut:

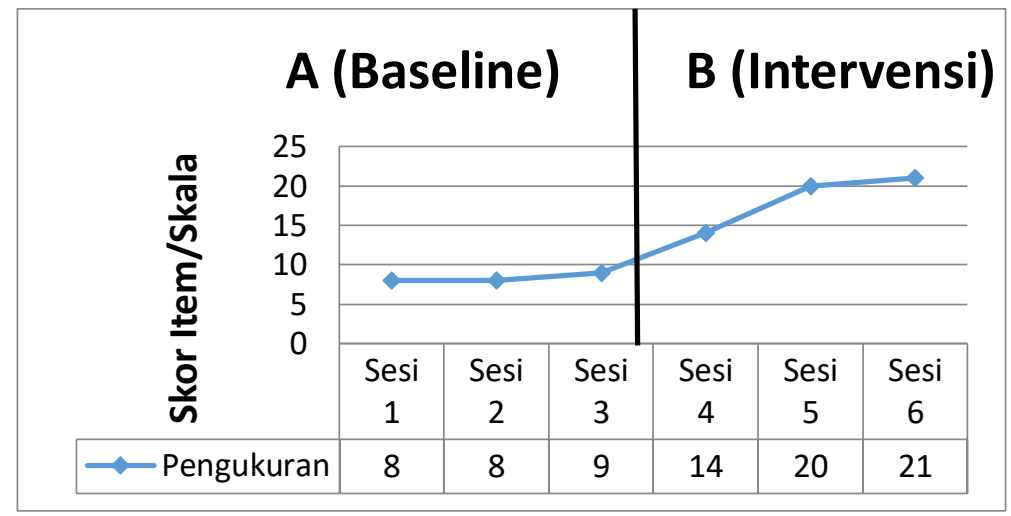

Gambar 4. Grafik kondiri self-efficacy RW Terhadap Pelajaran Matematika Sebelum dan Setelah Intervensi

Gambar 4 menunjukkan terjadinya peningkatan self-efficacy RW terhadap pelajaran matematika setelah diberikan intervensi. Analisis terhadap grafik menunjukkan titik level skor terus meningkat, dan pada sesi pengukuran ke 5 dan ke 6 titik level grafik cenderung stabil. Rata-rata skor self-efficacysecara keseluruhan pada baseline sebesar 8,3 dan setelah diberikan intervensi meningkat menjadi 18,3 atau terjadi peningkatan sebesar 10 poin. Peningkatan skor tersebut mengindikasikan sejak diberikan intervensi, skorself-efficacy terus meningkat dan tidak kembali pada level baseline. Artinya konseling cognitive behavioralefektif untuk meningkatkan self-efficacy RW terhadap pelajaran matematika.

Self-efficacy merujuk pada kekuatan keyakinan diri individu untuk mampu melakukan sebuah tugas atau kegiatan, serta berpengaruh kepada motivasi dan prestasinya. Proses konseling RW dilakukan bertujuan untuk membangun dan merekonstruksi ulang kognitif RW yang merasa bahwa ia tertinggal dengan teman- 
temannya dalam pelajaran matematika, dan lambat berfikir dalam soal hitungan. Inilah yang menjadi faktor RW merasa tidak ada lagi motivasi untuk mempelajari pelajaran matematika.Sehingga keyakinan negatif tersebut menjadikan persepsi dan daya kognitif RW lemah terhadap pelajaran matematika,sehingga memunculkan perilaku yang negatif terhadap matematika.Namun hasil penelitian menunjukan keyakinan dan persepsi negatif terhadap pelajaran matematika tersebut dapat di rekonstruksi kembali, yaitu dengan mengubah persepsi dan keyakinan dengan cara menyakinkan RW atas kemampuannya yang dikuatkan dengan banyak belajar dan latihan mengerjakan soal-soal matematika.Saat RW memiliki keyakinan untuk mengerjakan soal-soal matematika, maka keyakinanya tersebut akan menumbuhkan motivasi dan prestasinya.

2. Analisis hasil konseli AL setelah intervensi

Sama halnya dengan RW, konseli AL berpartisipasi selama tiga sesikonseling dan tiga sesi pengukuran. Grafik hasil pengukuran antara baseline dan intervensi disajikan sebagai berikut.

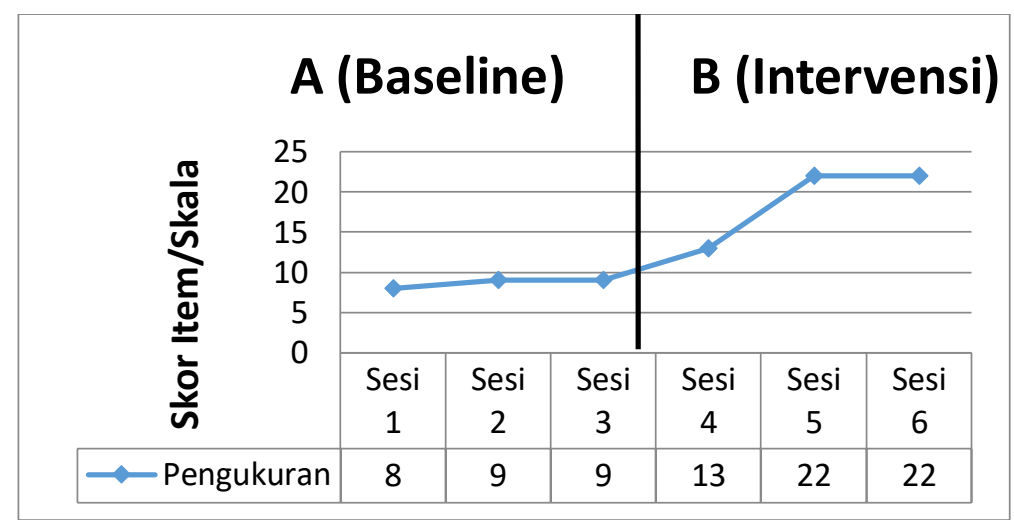

Gambar 5. Grafik kondiri self-efficacy AL Terhadap Pelajaran

Matematika Sebelum dan Setelah Intervensi

Gambar 5 menunjukkan terjadinya peningkatan self-efficacy RW terhadap pelajaran matematika setelah diberikan intervensi. Analisis terhadap grafik menunjukkan titik level skor skala self-efficacy RW terus meningkat, dan pada sesi pengukuran ke 5 dan ke 6 titik level grafik cenderung stabil. Rata-rata skor selfefficacy secara keseluruhan pada baseline sebesar 8,6 dan setelah diberikan intervensi meningkat menjadi 19 atau terjadi peningkatan sebesar 10,4 poin. Peningkatan skor tersebut mengindikasikan sejak diberikan intervensi, skor selfefficacy terus meningkat dan tidak kembali pada level baseline. Artinya konseling cognitive behavioral efektif untuk meningkatkan self-efficacy AL terhadap pelajaran matematika.

Sebagaimana diketahui bahwa AL masuk ke SMA tempat penelitian ini melalui jalur prestasi renang, dan dirinya lebih banyak meluangkan waktu untuk latihan renang dari pada mempelajari matematika, bahkan ia malas untuk mempelajari matematika, dan dirinya berpersepsi bahwa matematika tidak ada hubungannya dengan aktifitas renang, sehingga cenderung mengabaikan pelajaran matematikan dan lebih mementingkan latihan renang. Maka konseling yang dilakukan terhadap AL berfokus pada merubah persepsi kognitifnya yang menganggap pelajaran matematika tidaklah penting baginya. Hasil penelitian menunjukan adanya 
peningkatan self-efficacy AL terhadap pelajaran matematika. Jadwal untuk belajar matematika yang telah dibuat oleh AL telah dilaksanakan dengan baik, mengingat AL adalah siswa yang memiliki skor IQ dengan kualifikasi sangat cerdas, maka seharusnya tidaklah sulit bagi AL untuk mempelajari matematika. Saat AL mampu memahami dan mengerjakan soal-soal matematika, maka keyakinan dan persepsinya terhadap pelajaran matematika akan tumbuhkearah perubahan yang positif.

3. Analisis hasil konseli RN setelah intervensi

Konseli RN berpartisipasi selama tiga sesi konseling dan tiga sesi pengukuran. Grafik hasil pengukuran antara baseline dan intervensi disajikan pada Gambar 6.

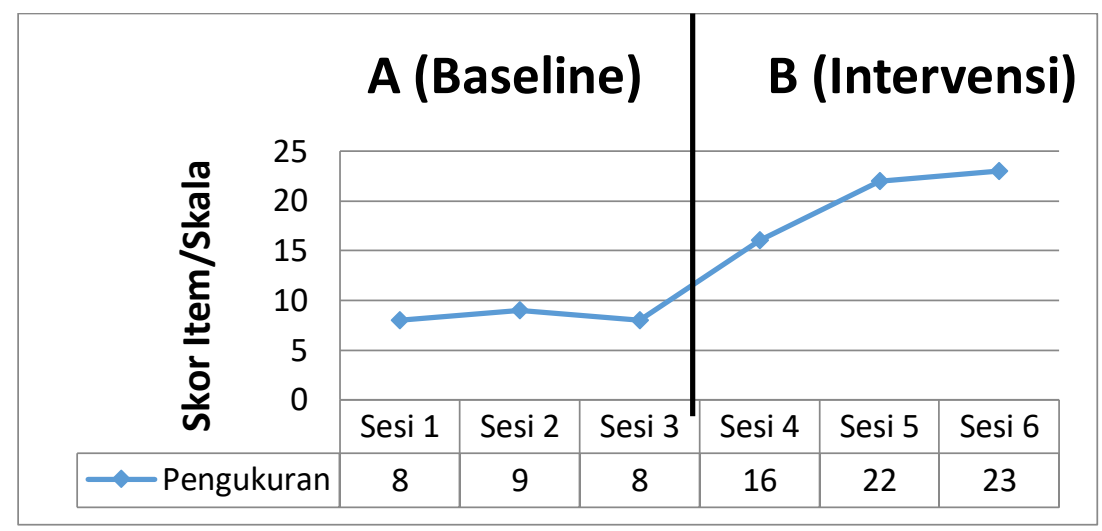

Gambar 6. Grafik Kondiri Self-Efficacy RN terhadap Pelajaran Matematika Sebelum dan Setelah Intervensi

Gambar 6 menunjukkan terjadinya peningkatan self-efficacy RN terhadap pelajaran matematika setelah diberikan intervensi. Titik level skor menunjukan skala self-efficacy RN terus meningkat, dan pada sesi pengukuran ke 5 dan ke 6 titik level grafik cenderung stabil. Rata-rata skor self-efficacy secara keseluruhan pada baseline sebesar 8,3 dan setelah diberikan intervensi meningkat menjadi 20,3 atau terjadi peningkatan sebesar 12 poin. Peningkatan skor tersebut mengindikasikan sejak diberikan intervensi, skor self-efficacy terus meningkat dan tidak kembali pada level baseline. Artinya konseling cognitive behavioral efektif untuk meningkatkan self-efficacy $\mathrm{RN}$ terhadap pelajaran matematika.

Masalah utama yang dialami $\mathrm{RN}$, ia kurang mampu dalam menghafal dan memahami rumus-rumus matematika, sehingga dirinya merasa kurang mampu untuk mempelajari matematika, serta tidak ada usaha untuk mempelajari matematika. Kendatipun demikian, berdasarkan deskripsi hasil pemerikasaan psikotes, RN memiliki skor IQ dengan kualifikasi sangat cerdas, dan bakat dalam bidang matematika menunjukan tingkat potensi yang sedang. Maka konseling yang dilakukan terhadap $\mathrm{RN}$ berfokus pada merubah persepsi kognitifnya yang menganggap pelajaran matematikaitu sulit. Mengingat RN memiliki kualifikasi IQ yang sangat cerdas, maka permasalahannya bukanlah terletak pada lambatnya RN dalam berfikir dan memahami pelajaran matematika. Hasil penelitian menunjukan adanya peningkatan self-efficacy $\mathrm{RN}$ terhadap pelajaran matematika. ketikaRN mampu memahami dan mengerjakan soal-soal matematika dan menjadi sebuah pengalaman yang baru dalam hidupnya, maka keyakinan dan persepsinya terhadap pelajaran matematika tumbuh kearah perubahan yang positif. 


\section{Analisis Penelitian CBT untuk Meningkatkan Self-Efficacy Siswa dalam Pelajaran Matematika}

Dari 3 konseli yang menjadi subjek penelitian ditemukan bahwa setelah diberikan intervensi konseling cognitive behavioralskor self-efficacy siswa mengalami peningkatan secara signifikan. Hasil penelitian konseling cognitive behavioral untuk meningkatkan self-efficacy sebagai berikut:

Tabel 3. Perbedaan Rata-rata Skor Self-Efficacy antara Baseline dan Intervensi

\begin{tabular}{cccc}
\hline Nama Konseli & Rata-Rata Baseline & Rata-Rata Intervensi & Selisih \\
\hline RW & 8,3 & 18,3 & 10 \\
\hline AL & 8,6 & 19 & 10,4 \\
\hline RN & 8,3 & 20,3 & 12 \\
\hline
\end{tabular}

Berdasarkan data penelitian yang telah dipaparkan sebelumnya, dapat disimpulkan bahwa konseling cognitive behavioral efektif untuk meningkatkan self-efficacy siswa terhadap pelajaran matematika. Fakta tersebut sesuai dengan temuan-temuan penelitian sebelumnya, seperti yang diungkapkan oleh Keshi (2013), dalam penelitiannya terhadap siswa SMA yang menemukan bahwa program CBT berpengaruh signifikan positif dan secara kongkrit mampu meningkatkan self-efficacy. Sejalan dengan Keshi (2013) dan Clark \& Beck (2010) menemukan bahwa di sebagian besar program CBT, individu akan meningkatkan keterampilan sosial, self-concept dan self-efficacy mereka.

\section{KESIMPULAN}

CBT merupakan konseling yang menitikberatkan pada restrukturisasi atau pembenahan kognitif yang menyimpang akibat kejadian yang merugikan dirinya baik secara fisik maupun psikis. Aspek kognitif dalam CBT antara lain mengubah cara berpikir, kepercayaan, sikap, asumsi, imajinasi dan memfasilitasi konseli belajar mengenali dan mengubah kesalahan dalam aspek kognitif. Sedangkan aspek behavioral dalam CBT yaitu mengubah hubungan yang salah antara situasi permasalahan dengan kebiasaan mereaksi permasalahan, belajar mengubah perilaku, menenangkan pikiran dan tubuh sehingga merasa lebih baik, serta berpikir lebih jelas.

Konsekuensi psikologis dari lemahnya self-efficacy pada matematika adalah munculnya sikap negatif yang mengarah kepada motivasi yang rendah dan apatis terhadap pelajaran matematika. Oleh karena itu, tanpa meningkatkan dan mengandalkan pembelajaran matematika yang berkualitas yang menuntun siswa untuk berpikir, akan sangat sulit untuk dapat tercapai kemampuan berpikir agar menghasilkan sebuah hasil prestasi belajar matematika yang baik. Oleh karena itu, perlu dikembangkan kemampuan berpikir dalam proses pembelajaran matematika. Siswa yang telah belajar matematika diharapkan bukan hanya menghafal rumus dan prosedur untuk menyelesaikan soal-soal matematika saja namun memiliki pemahaman dan kemampuan berpikir logis dan baik yang terintegrasi atau menyatu menjadi bagian dalam diri siswa dan kelak dapat berguna dalam menyelesaikan berbagai masalah dalam kehidupan siswa tersebut. 
Menurut teori kognitif sosial Bandura (1994), self-efficacy mempengaruhi pilihan orang dalam membuat dan menjalankan tindakan yang mereka kejar. Individu cenderung berkonsentrasi dalam tugas- tugas yang mereka rasakan mampu dan percaya dapat menyelesaikannya serta menghindari tugas-tugas yang tidak dapat mereka kerjakan. Merubah self-efficacy berarti merubah pola pikir, dan jenis konseling yang dapat dilakukan adalah CBT. Self-efficacy memiliki korelasi dengan strategi CBT dalam mengubah pikiran individu, perilaku, emosi, dan prestasi individu (Bandura, 1997). Dan Hall \& Hughes (1989) mengatakan, pengalaman pada sesi konseling memberikan kesempatan kepada siswa untuk tidak menghindari masalah melainkan memikirkan cara yang mampu dilakukannya untuk menyelesaikan masalah tersebut, sehingga muncul keyakinan pada diri akan kemampuannya menyelesaikan permasalahan.

\section{REFERENSI}

Alwisol. (2010). Psikologi Kepribadian. Malang: UMM Press.

Auliya, R.N. (2013). Pengaruh Model Pembelajaran Kooperative Tipe CRH (Course, Review, Hurray) Terhadap Kemampuan Pemahaman Matematis dan Kecemasan Siswa SMP (Tesis Pendidikan Matematika tidak diterbitkan). Universitas Pendidikan Indonesia, Bandung.

Bandura, A. (1993). Perceived Self Efficacy in cognitive development and functioning. Educational Psychologist, 28, 117-148.

Bandura, A. (1994). Self-efficacy. In V. S. Ramachaudran (Ed.), Encyclopedia of human behavior. (Vol. 4, pp. 71-81). New York: Academic Press.

Bandura, A. (1997). Self-efficacy: The exercise of control. New York: Freeman.

Bandura, A., Barbaranelli, C., Caprara, G. V., \& Pastorelli, C. (1996). Multifaceted impact of self-efficacy beliefs on academic functioning. Child Development, 67(3), 1206-1222.

Beck, A. T. (1964). Thinking and Depression: Theory and Therapy. Archives of General Psychiatry, 10, 561-571.

Beck, J. S. (2011). Cognitive behavior therapy: Basics and beyond. 2nd ed. London: Guilford.

Bush, J.W. (2003). Cognitive Behavioral Therapy: The Basics [HTML file]. Tersedia: http://cognitivetherapy.com/basics.html.

Clark, D.A., \& Beck, A.T. (2010). Cognitive therapy of anxiety disorders: Science and practice. New York: Guilford Press.

Erfantinni, I. H., Purwanto, E., \& Japar, M. (2016). Konseling Kelompok Cognitive-Behavior Therapy dengan Teknik Cognitive Restructuring untuk Mereduksi Prokrastinasi Akademik. Jurnal Bimbingan Konseling, 5(2), 119125.

Feist, J., \& Feist, G. J. (2009). Theories of personality. USA: McGraw Hill Higher Education

Hall, R. J. \& Hughes, J. N. (1989). Cognitive Behavioral Approaches in the Schools: A Comprehensive Handbook. New York: The Guilford press.

Hellum-Alexander, A. (2010). Effective teaching strategies for alleviating math anxiety and increasing self-efficacy in secondary students (Unpublished Thesis). Evergreen State College, United States. 
Hidayat, A. S. (2010). Pokok Pokok Pengajaran Matematika [PDF file]. Tersedia: http://file.upi.edu/Direktori/FPMIPA/JUR._PEND._MATEMATIKA/19580 4011985031-ASEP_SYARIF_HIDAYAT/Pokok-2_peng_mat.pdf.

Keshi, A. K. (2013). Effectiveness of cognitive behavior therapy on self-efficacy among high school students. Asian journal of management sciences \& education, 2(4), 68-79.

Kumar, G. V. \& Sebastian, L. (2011). Impact of CBT on self-efficacy and academic achievement in adolescent's students. Journal of the Indian academy of applied psychology, 37, 134-139.

Luszczynska, A., Mohamed, N. E., \& Schwarzer, R. (2005). Self-efficacy and social support predict benefit finding 12 months after cancer surgery: The mediating role of coping strategies. Psychology, Health \& Medicine. 10, 365375.

Lusby, B. (2009). Increasing Student's Self-efficacy in Mathematics [PDF file] Tersedia: http://www.smcm.edu/educationstudies/pdf/rising-tide/volume5/lusby.pdf.

Matson, J. L., \& Ollendick, T. H. (1988). Enhancing Children's Social Skills: Assessment and Training. London: Pergamon Press.

Mukhid, A. (2009). Self-Efficacy (Perspektif Teori Kognitif Sosial dan Implikasinya terhadap Pendidikan). TADRIS: Jurnal Pendidikan Islam, 4(1), 106-122.

NACBT. (2007). Cognitive-Behavioral Therapy [HTM file]. Tersedia: http://www.nacbt.org/whatiscbt.htm.

Oemarjoedi, A. K. (2003). Pendekatan Cognitive Behavior dalam Psikoterapi. Jakarta: Kreativ Media.

Ormrod, J. E., Anderman, E. M., \& Anderman, L. H. (2006). Educational psychology: Developing learners. Ohio: Pearson.

Pajares, F., \& Miller, M. D. (1995). "Mathematics self-efficacy and mathematics outcomes: The need for specificity of assessment". Journal of Counseling Psychology, 42, 190-198.

Priatna, N. (2008). Karakteristik Matematika [PDF file]. Tersedia: http://file.upi.edu/Direktori/FPMIPA/JUR._PEND._MATEMATIKA/19630 3311988031-NANANG_PRIATNA/Karakteristik_Matematika.pdf.

Sabandar, J. (2009a). Berpikir Reflektif [PDF file]. Tersedia: http://file.upi.edu/Direktori/FPMIPA/JUR._PEND._MATEMATIKA/19470 5241981031-JOZUA_SABANDAR/KUMPULAN_MAKALAH_DAN_ JURNAL/Berpikir_Reflektif2.pdf.

Sabandar, J. (2009). Thinking Classroom dalam Pembelajaran Matematika di. Sekolah [PDF file]. http://file.upi.edu/Direktori/FPMIPA/JUR._PEND._MATEMATIKA/19470 5241981031-JOZUA_SABANDAR/KUMPULAN_MAKALAH_DAN_ JURNAL/Thinking-Classroom-dalam-Pembelajaran-Matematika-diSekolah.pdf.

Schoenfeld, A. H. (2016). Learning to think mathematically: Problem solving, metacognition, and sense making in mathematics (Reprint). Journal of Education, 196(2), 1-38. 
Sloan, T., Daane, C. J., \& Giesen, J. (2002). Mathematics anxiety and learning styles: What is the relationship in elementary preservice teachers?. School Science and Mathematics, 102(2), 84-87.

Sopiyah, S. (2016). Peningkatan Self-Efficacy Pada Siswa Melalui Konseling Cognitive Behavioral. JBKI: Jurnal Bimbingan Konseling Indonesia, 1(2), 26-28.

Tansil, S., Aditomo, A., \& Tjahjono, E. (2009). Reflected Appraisals dan Mathematic Academic Self-Efficacy pada Siswa SMA. ANIMA Indonesian Psychological Journal, 24(2), 183-188.

Yahya, A. D., \& Megalia, M. (2016). Pengaruh Konseling Cognitif Behavior Therapy (CBT) dengan Teknik Self Control untuk Mengurangi Perilaku Agresif Peserta Didik Kelas VIII di SMPN 9 Bandar Lampung Tahun Pelajaran 2016/2017. KONSELI: Jurnal Bimbingan dan Konseling (EJournal), 3(2), 126-140. 